\title{
DOES QUALITY OF BUSINESS ENVIRONMENT INFLUENCE FOREIGN DIRECT INVESTMENT INFLOWS? A CASE OF CENTRAL EUROPEAN COUNTRIES
}

\author{
Aneta Bobenič Hintošová, Zuzana Kubíková, Rastislav Ručinský
}

\begin{abstract}
This paper investigates the effect of selected business environment indicators on FDI inflows in case of Visegrad countries for the period of 2005-2015. Based on correlation and regression analysis, it is concluded that the business environment matters significantly for FDI inflows, however the direction and strength of dependence differs according to analysed factors. We found that better global competitiveness of the country leads to higher volume of inward FDI the country receives. However, economically more free country, which is more globalized, with better rating, does not attract more FDI inflows, but rather the opposite. As expected, corruption of country is discouraging foreign investors from investing in Visegrad countries.
\end{abstract}

\section{Key words}

business environment, foreign direct investments, globalization, ease of doing business, global competitiveness, economic freedom, rating, corruption perception index

\section{Introduction}

Foreign direct investments (hereinafter also „FDI“) are widely discussed topic from different points of view. Generally, countries at a similar level of economic development, attracting more FDI are considered more competitive. Important role in this respect is attributed to a quality of business environment of a particular country.

One of the main characteristics of business environment in the recent years is globalization. The impact of globalization on economic conditions and growth of countries is examined in a number of studies, where the globalization is measured with Globalization Index published by KOF Swiss Economic Institute (e.g. Chang and Lee, 2011; Elmawazini et al. 2013, Elsherif, 2016; Gurgul and Lach, 2014).

The effect of globalization on economic growth of former communist countries, such as Hungary, the Czech Republic, Poland, and Slovakia, was found positive and statistically significant in study by Chang and Lee (2011). Authors concluded that advanced globalization has substantial effect on economic performance of countries. When studying the process of economic globalization, many authors emphasize the impact of FDI (e.g. Casi and Resmini, 2012; Vertter, 2014). Pekarskiene and Susniene (2015) stated that the indicators of FDI, such as inward and outward position, FDI inflows and outflows, etc. enable to asses all aspects - scope, scale, direction, and speed of the globalization level. However, the possible effect of globalization on FDI was studied only in a very limited number of studies, to our knowledge. One of very few was a study by Yang, Lu, and Jiang (2016), who studied the speed of FDI and their effects on firm performance. They found relationship between FDI and performance, which varied with the different level of globalization of industrial environment, in which the firms operated. 
Besides partial factors describing level of business environment development, such as GDP, inflation, employment, etc., also more complex indicators of business environment are used within empirical studies. Specifically, Doing Business data, published by The World Bank, and their relation to FDI flows were examined in the recent work of Corcoran and Gillanders (2015), which is built on previous less complex studies. The authors showed that Doing Business rank is highly significant, when included in a standard empirical foreign direct investment model, however, the significance of the overall Doing Business is driven by Ease of Trading Across Borders component. According to them, the relationship is significant for middle income countries, but not for the world's poorest regions, where better business environments are not associated with greater levels of FDI.

Another recent study using composite indicator for evaluation the nation's environment is a study performed by Sambharya and Rasheed (2015) where, besides the others, the relation between Index of Economic Freedom (The Heritage Foundation) and FDI inflows was investigated. Their results indicate that better economic management (monetary policy, fiscal burden and banking and finance), less government participation in the economy, less state intervention (strong property rights, less regulation, low prevalence of informal markets and less corruption), absence of wage and price controls, and higher levels of political freedom lead to higher FDI inflows.

In addition, business environment is related to institutional environment of country. Henisz (2003) suggests that institutional environment consists of factors such as property rights, protection of intellectual property, taxes, corruption, political risk, banking and financial policies. When a country has strong institutions, it becomes an attractive destination for FDI, because it lowers cost of transaction by making the host country market more efficient, for example by discouraging corruption, etc. (Bevan et al., 2004). The negative impact of corruption on FDI is documented in a number of empirical studies (e.g. Globerman and Shapiro, 2003; Zhao et al., 2003; Wei, 2000). Corruption discourages firms from investing in a country, slows down economic growth and thus makes the country unattractive from foreign investor's point of view.

However, similar studies conducted specifically in the conditions of Central European countries are rather rare. Witkowska (2007) in her work dealt with foreign direct investments in the changing business environment of the European Union's new member states, and without deeper quantitative analysis she generally concluded that business environment can be treated as an important location factor as far as FDI is concerned. Another similar study performed by Šimelyté and Liučvaitiené (2012), although focusing primarily on the FDI policy, showed that Baltic countries, as well as Visegrad countries attempt to create a friendly business environment by means of similar methods. The results of attracting FDI are better in Visegrad countries, which implement financial incentives toward inward FDI along with fiscal incentives. According to empirical analysis, it is noticed that a higher intervention level and a higher support level guarantee the volume of inward FDI.

Our ambition is to contribute to existing literature by analysing the relation between a level of business environment measured by various indicators capturing different aspects of business environment and a level of inward FDI in Visegrad countries (Slovakia, the Czech Republic, Hungary, Poland). The aim of the paper is to identify, whether the quality of business environment is associated with more FDI inflows, and to test, how the key indicators influence the volume of FDI inflows. The main hypothesis tested in this paper is that business environment with higher quality, characterized by globalization of host country, greater ease of doing 
business, higher economic freedom, better country rating, and lower level of corruption, will attract more FDI inflows.

\section{Methodology}

In this paper, data about business environment of four Visegrad countries - the Czech Republic, Hungary, Poland, and Slovakia, are used. The dependent variable, we worked with in this paper is FDI inflow, as reported by the FDI/TNC database of UNCTAD. As independent variables, we used following complex of indicators to capture various aspects of business environment:

Ease of Doing Business (The World Bank) is an economy ranking, which evaluates ease of doing business in particular economy. The high ranking means that the regulatory environment is more conducive to the starting and operation of a local firm.

Global Competitiveness Index (The World Economic Forum), integrates the macroeconomic and the micro and business aspects of competitiveness, and assesses the ability of countries to provide high levels of prosperity to their citizens, by measuring the set of institutions, policies, and factors that set the sustainable current and medium-term levels of economic prosperity. The ranking of countries is used in this paper, which means that lower values indicate better position.

In case of Index of Economic Freedom (The Heritage Foundation) the index values are used and higher values are associated with higher quality of business environment. This index measures the impact of liberty and free markets around the globe.

The country credit Rating was evaluated according to credit rating of agency Moody's, which performs international financial research and analysis on commercial and government entities, and ranks the credit-worthiness of borrowers using a standardized ratings scale. The letter rating was transformed into numbers.

Corruption Perception Index (Transparency International) is used as characteristic of institutional business environment, and it is scoring countries on how corrupt their public sectors are seen to be. The higher score represents more corruption in country, and it captures the informed views of analysts, business people and experts in countries around the world.

KOF Index of Globalization (Swiss Federal Institute of Technology Zurich) measures economic, social, and political dimension of globalization. It takes actual economic flows, economic restrictions, information flows, and cultural proximity into consideration. The higher scores represent more globalized country.

We investigated the effect of the business environment on FDI inflows using pooled annual data for the period of 2005-2015 for four Visegrad countries. In this paper, the following regression model is used to assess the impact of all independent variables on FDI inflow (FDI):

$$
F D I_{i, t}=\alpha_{i, t}+\beta X_{i, t-1}+\varepsilon_{i, t}
$$

In equation, $i$ and $t$ denote a country and time subscripts, respectively. is a constant, andis the error term. The dependent variable $F D I_{i, t}$ refers to the FDI inflow in time $t$, which is expected to be influenced by the vector of the independent variables observed in the previous period $t-1$. is the vector of parameter coefficients to be estimated. Before conducting the regression analysis, the correlations between all pairs of variables is performed. 
Table 1 introduces the Pearson correlation coefficients between pairs of all variables. We did not find high correlation between pairs of independent variables, what leads to no suspicion of multicollinearity problem in a regression model. However, we use the VIF (Variance Inflation Factors) to test a possible collinearity problem in the model. Based on correlation coefficients, the positive effect of the variable Ease of Doing Business, while the negative effects of the variables Index of Economic Freedom, Global Competitiveness Index, Corruption Perception Index, Rating, and KOF Index of Globalization on FDI inflow are expected in the regression model.

\begin{tabular}{|c|c|c|c|}
\hline & $\begin{array}{c}\text { Ease } \\
\text { of Doing Business }\end{array}$ & $\begin{array}{c}\text { Index } \\
\text { of Economic } \\
\text { Freedom }\end{array}$ & $\begin{array}{c}\text { Global } \\
\text { Competitiveness } \\
\text { Index }\end{array}$ \\
\hline FDI Inflow & $\begin{array}{c}0.4438^{\star * *} \\
(0.0067)\end{array}$ & $\begin{array}{c}-0.6966^{* * *} \\
(0.0000)\end{array}$ & $\begin{array}{l}-0.2666 \\
(0.1160)\end{array}$ \\
\hline Ease of Doing Business & 1.0000 & $\begin{array}{c}-0.3905^{\star *} \\
(0.0185)\end{array}$ & $\begin{array}{c}-0.205 \\
(0.2304)\end{array}$ \\
\hline Index of Economic Freedom & & 1.0000 & $\begin{array}{l}-0.0063 \\
(0.9707) \\
\end{array}$ \\
\hline \multirow[t]{2}{*}{ Global Competitiveness Index } & & & 1.0000 \\
\hline & $\begin{array}{c}\text { Corruption } \\
\text { Perception Index }\end{array}$ & Rating & $\begin{array}{c}\text { KOF Index } \\
\text { of Globalization }\end{array}$ \\
\hline FDI Inflow & $\begin{array}{l}-0.1751 \\
(0.3071)\end{array}$ & $\begin{array}{l}-0.1398 \\
(0.4161)\end{array}$ & $\begin{array}{c}-0.5602^{* * *} \\
(0.0004)\end{array}$ \\
\hline Ease of Doing Business & $\begin{array}{l}-0.0111 \\
(0.9486) \\
\end{array}$ & $\begin{array}{c}0.0804 \\
(0.6410) \\
\end{array}$ & $\begin{array}{c}-0.3374^{\star \star} \\
(0.0442) \\
\end{array}$ \\
\hline Index of Economic Freedom & $\begin{array}{c}0.1734 \\
(0.3120) \\
\end{array}$ & $\begin{array}{c}0.1186 \\
(0.4908) \\
\end{array}$ & $\begin{array}{c}0.5464^{\star * *} \\
(0.0006)\end{array}$ \\
\hline Global Competitiveness Index & $\begin{array}{l}-0.1593 \\
(0.3534) \\
\end{array}$ & $\begin{array}{c}-0.4000^{\star *} \\
(0.0156)\end{array}$ & $\begin{array}{c}0.1297 \\
(0.4507) \\
\end{array}$ \\
\hline Corruption Perception Index & 1.0000 & $\begin{array}{l}-0.2111 \\
(0.2166) \\
\end{array}$ & $\begin{array}{c}0.1259 \\
(0.4644) \\
\end{array}$ \\
\hline Rating & & 1.0000 & $\begin{array}{c}-0.3001^{\star} \\
(0.0754) \\
\end{array}$ \\
\hline KOF Index of Globalization & & & 1.0000 \\
\hline
\end{tabular}

Notes: The values in parentheses are the $\mathrm{p}$-values for the Pearson correlation coefficient. According to $\mathrm{p}$-values, ${ }^{*},{ }^{* *},{ }^{* * *}$ and denotes a statistical significance at the level of $.10, .05$, and .01 , respectively.

\section{Table 1 Pearson correlation matrix}




\section{Empirical results and discussion}

Table 2 shows the empirical results of pooled OLS parameter estimation of the model (1). The reported numbers for each variable are coefficients and their standard errors, $t$-ratios, $\mathrm{p}$ values, and asterisks denoting levels of statistical significance, based on p-values. The variables Global Competitiveness Index, KOF Index of Globalization, Rating, and constant are statistically significant at the level of .01. Index of Economic Freedom is statistically significant at the level of .05, and the variable Corruption Perception Index is statistically significant at the level of .10. The variable Ease of Doing Business is not statistically significant determinant of FDI inflow in the model (1).

The value of the coefficient of determination indicates that the model can explain $72 \%$ of the variation in the dependent variable. The low p-value of F-statistic confirms the significance of the regression model. Reported Durbin-Watson statistic does not indicate serial autocorrelation problem in the model. The White's test for heteroskedasticity with a high p-value does not lead to rejection of the null hypothesis that there is no heteroskedasticity problem in the model. The high p-values of F-test of joint significance of differing group means, and BreuschPagan LM statistic does not lead to rejection of the null hypothesis that the pooled OLS model is adequate. These test results suggest that the application of fixed or random effects are not suitable in the model. The test for normality of residuals with a high p-value leads to rejection of null hypothesis that error is normally distributed. Normality of residuals is not a crucial assumption for this model. In spite of this fact, we checked the results of the model (1) with robust method, not influenced by outliers, which showed very similar results, and the same signs of particular variables, only the statistical significance of all variables was lower, what meant that variable Corruption Perception Index had no statistical significant impact on FDI inflow. However, robust method confirmed the results of pooled OLS estimation, and we will interpret these in the following part. 


\begin{tabular}{l|c|c|c|c}
\hline FDI Inflow & Coefficient & Std. Error & t-ratio & p-value \\
\hline Constant & $133439^{* * *}$ & 22085.4 & 6.0420 & $<0.00001$ \\
\hline Ease of Doing Business & 48.3274 & 41.5956 & 1.1618 & 0.25477 \\
\hline Index of Economic Freedom & $-515.088^{* *}$ & 192.561 & -2.6749 & 0.01216 \\
\hline Global Competitiveness Index & $-165.978^{* * *}$ & 47.5954 & -3.4873 & 0.00158 \\
\hline KOF Index of Globalization & $-735.895^{* * *}$ & 264.976 & -2.7772 & 0.00951 \\
\hline Corruption Perception Index & $-1984.25^{*}$ & 985.152 & -2.0142 & 0.05335 \\
\hline Rating & $-1182.64^{* * *}$ & 353.963 & -3.3411 & 0.00231 \\
\hline Sum of squared residuals & $2.45 \times 10^{8}$ & & S.E. & 2903.709 \\
\hline R2 & 0.717647 & & Adjusted R2 & 0.659230 \\
\hline F(8. 27) & 12.28474 & & with p-value & $7.54 \times 10^{-7}$ \\
\hline Durbin-Watson & 2.520097 & & with p-value & 0.880374 \\
\hline Whites test & 27.7208 & & with p-value & 0.425477 \\
\hline Test for normality & 0.0362229 & & with p-value & 0.982052 \\
\hline F-test & 1.93473 & & with p-value & 0.14875 \\
\hline Breusch-Pagan test & 1.6186 & & with p-value & 0.203288 \\
\hline
\end{tabular}

Notes: The model tested for a collinearity problem with use of VIF (Variance Inflation Factors) test pass the test at cut-off value equal to 2. Since only values higher than 10.0 may indicate a collinearity problem, we do not need to correct for multicollinearity in the model. According to p-values, ${ }^{*}{ }^{* *},{ }^{* *}$ and denotes a statistical significance at the level of $.10, .05$, and .01 , respectively.

Source: Authors' calculations.

\section{Table 2 Pooled OLS estimation of coefficients}

The variables with the highest statistical significance in the model are Global Competitiveness Index, KOF Index of Globalization, and Rating, all of them having high negative impact on FDI inflow as expected. In case of Global Competitiveness Index, the ranking of countries was used, so better position in the ranking of global competitiveness, thus lower value, leads to higher FDI inflows. In particular, when country falls in a ranking of global competitiveness by one level, the volume of FDI inflow decreases by around 166 mil. USD. This finding is partially in line with conclusions of Prime, Subrahmanyam and Lin (2012) who explained receiving of substantially more FDI in China in comparison to India by China's sustainable competitive advantage. The higher values of country credit Rating, indicating less risky investment environment, are surprisingly associated with lower FDI inflows. One level increase in credit rating causes decrease in volume of FDI inflow by 1183 mil. USD. It may be caused by expectations of the foreign investors that better country credit rating is associated with higher level of economic development and higher costs. Similarly, higher level of globalization is associated with lower FDI inflows. Particularly, one point increase in KOF index leads to decrease of FDI inflow volume by 736 mil. USD. Globalization of host country may induce more challenging market demand, better skilled labour, demanding higher wages, more competition etc., which all can lead to discouraging of foreign investors from entering the market, meaning lower FDI inflows. 
The second highest statistical significance has Index of Economic Freedom, with high negative impact on the dependent variable, as well. When country increases in this index by one point, the volume of FDI inflow decreases by 515 mil. USD. Higher values of the index, indicating economically free society, are associated with lower values of inward FDI a-vice-versa. This finding is rather in contrast with the results of Sambharya and Rasheed (2015).

Negative, high, and statistically significant impact has also been found for the variable Corruption Perception Index, where one point increase in index led to decrease in FDI inflow by 1 984 mil. USD. This result is in line with previous studies by Sambharya and Rasheed (2015), who found highly negative and statistically significant impact of corruption on FDI. Clearly, higher corruption discourages foreign investors, due to less transparent transactions, more costly bureaucracy, and less honest institutional environment of host country.

Positive, but statistically not significant impact is found for the variable Ease of Doing Business, where ranking of countries was used and better position by one level from the ease of doing business point of view indicates lower FDI inflows by 48 mil. USD. On the contrary, Corcoran and Gillanders (2015) found negative and statistically significant effect of this variable on FDI. However, authors mentioned that most of this effect is explained solely by how easy is to trade across borders, with other components of Ease of Doing Business having little or no effect, and also that the effect was not present in all countries, indicating its country-specificity.

Similarly, as Gani and Al-Abri (2013) for Gulf Cooperation Council countries, we can also conclude that the business environment matters significantly for FDI inflows in Visegrad countries, however, the direction and strength of dependence differs according to analysed factors.

\section{Conclusion}

Our ambition within this empirical study was to verify the primary hypothesis, whether better quality of business environment, measured by different composite indicators, leads to higher inward FDI in conditions of Visegrad countries. Our results are rather controversial. On one hand we found that the better global competitiveness of the country the higher volume of inward FDI the country receives. On the other hand, more globalized, economically more free country, with better rating does not attract more FDI inflows, but rather the opposite. In case of Visegrad countries as expected, the higher corruption perception of country leads to lower FDI inflows. From the possible further areas of study point of view, it would be interesting to study potential differences among studied countries as well as to analyse in more details partial aspects of studied indicators and their relation to FDI inflows. 


\section{Bibliography}

Bevan, A., Estrin, S. and Meyer, K.E., 2004. Institution building and the integration of Eastern Europe in international production. International Business Review, vol.13, no.1, pp.43-64, ISSN 0969-5931

Casi, L., Resmini, L., 2012. Globalization, foreign direct investments and growth in European regions: An empirical assessment. In: Capello, R., Dentinho, T. P. (Ed.) Globalization Trends and Regional Development, Edward Elgar Publishing, 2012, p. 296, ISBN: 9781781003046

Chang, C.-P., Lee, C.-C., 2011. The Effect of Globalization and Political Party on Economic Growth: Panel Data Analysis of Former Communist Countries and European OECD Members. Eastern European Economics, vol. 49, no. 6, 2011, pp. 5-26, ISSN 1557-9298

Corcoran, A., Gillanders, R., 2015. Foreign direct investment and the ease of doing business. Review of World Economics, vol. 151, no. 1, pp. 103-26, ISSN 1610-2878

Elmawazini, K., Sharif, A., Manga, P., Drucker, P. 2013. Trade Globalization, Financial Globalization and Inequality Within South-East Europe and CIS Countries. The Journal of Developing Areas, vol. 47, no. 2, pp. 303-317, ISSN 0022-037X

Elsherif, M. A., 2016. The impact of globalization on economic conditions: empirical evidence from the Mena region. International Journal of Business and Economic Development, vol. 4, no. 1, pp. 1-14, ISSN 2051-8498

Gani, A., Al-Abri, A. S., 2013. Indicators of business environment, institutional quality and foreign direct investment in Gulf Cooperation Council countries. Internation Review of Applied Economics, vol. 27, no. 4, pp. 515-530, ISSN 0269-2171

Globerman, S., Shapiro, D., 2003. Governance infrastructure and US foreign direct investment. Journal of International Business Studies, vol. 34, no. 1, pp. 19-39. ISSN 1478-6990

Gurgul, H., Lach, L. 2014. Globalization and economic growth: Evidence from two decades of transition in CEE. Economic Modelling, vol. 36, pp. 99-107, ISSN 0264-9993

Henisz, W., 2003. The power of the Buckley and Casson thesis: the ability to manage institutional idiosyncracies. Journal of International Business Studies, vol. 34, no. 2, pp. 173-184, ISSN 1478-6990

Pekarskiene, I., Susniene, R., 2015 Features of foreign direct investment in the context of globalization. Procedia - Social and Behavioral Sciences, no. 213, pp. 204 - 210, ISSN 1877-0428

Prime, P. B., Subrahmanyam, V., Lin, C. M., 2012. Competitiveness in India and China: The FDI puzzle. Asia Pacific Business Review, vol. 18, no. 3, pp. 303-333, ISSN 1360-2381

Sambharya, R. B., Rasheed, A. A., 2015. Does economic freedom in host countries lead to increased foreign direct investment? Competitiveness Review, vol. 25, no. 1, pp. 2-24, ISSN 1059-5422

Swiss Federal Institute of Technology Zurich. KOF Index of Globalization. Updated [cit. 15/10/2016] Available from: http://globalization.kof.ethz.ch/

Šimelyté, A., Liučvaitiené, A., 2012. Foreign direct investment policy-friendly business environment in R\&D sectors: Baltic states versus Visegrad countries. Journal of East-West Business, vol. 18, no. 1, pp. 66-93, ISSN 1066-9868

The Heritage Foundation. Index of Economic Freedom. Updated [cit. 15/10/2016]. Available from: http://www.heritage.org/index/download

The World Bank. Doing Business. Updated [cit. 15/10/2016]. Available from: http://www.doingbusiness. org/reports/global-reports/doing-business-2015

The World Economic Forum. The Global Competitiveness Report. Updated [cit. 15/10/2016] Available from: http://reports.weforum.org/global-competitiveness-report-2014-2015/

Transparency International. Corruption Perception Index. Updated [cit. 15/10/2016] Available from: http://www.transparency.org/research/cpi/overview

Vetter, S. 2014. Recent Trends in FDI Activity in Europe. Deutsche Bank Research, pp. 1-11, ISSN 2193-5963 
Wei, S.J., 2000. How taxing is corruption on international investors? The Review of Economics and Statistics, vol. 82, no. 1, pp. 1-11, ISSN 1530-9142

Wei, S. Z. C., Zhu, Z., 2007. A revisit to the outward FDI determinants: further evidence from count panel data models with fixed effects. Applied Economics Letters, vol. 14, no. 11, pp. 809-812, ISSN 1350-4851

Witkowska, J., 2007. Foreign direct investments in the changing business environment of the European Union's new member states. Global Economy Journal, vol. 7, no. 4, pp. 1-32, ISSN 1524-5861

Yang, J. Y., Lu, J., Jiang, R. 2016. Too Slow or Too Fast? Speed of FDI Expansions, Industry Globalization, and Firm Performance. Long Range Planning, vol. 50, no. 1, pp. 1-20, ISSN 0024-6301

Zhao, J.H., Kim, S.H., Du, J. 2003. The impact of corruption and transparency on foreign direct investment. Management International Review, vol. 43, no. 1, pp. 41-62, ISSN 1861-8901

University of Economics in Bratislava

Faculty of Business Economics in Košice, Slovakia

Aneta Bobenič Hintošová aneta.bobenic-hintosova@euke.sk 